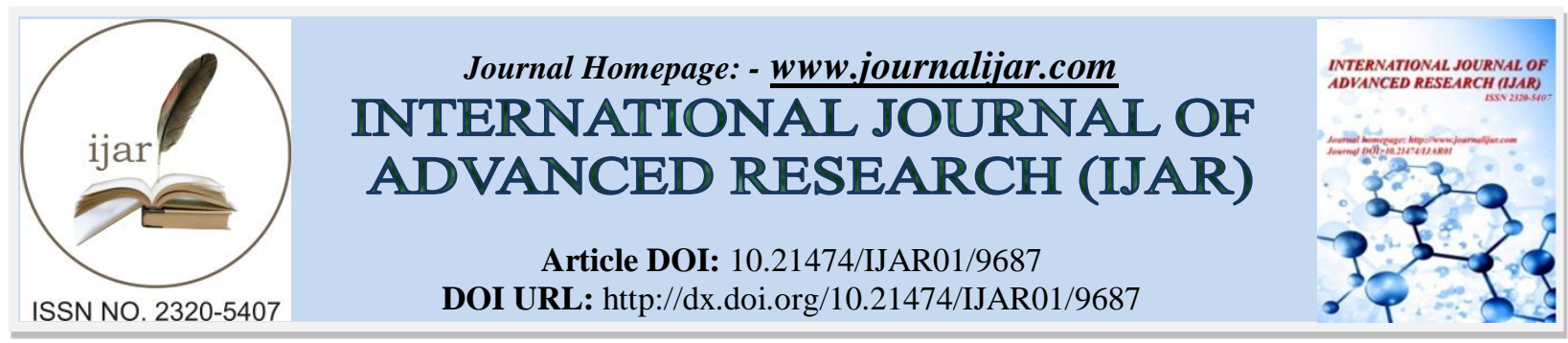

RESEARCH ARTICLE

\title{
STUDIES OF THERMAL COMFORT IN THE JAKARTA NORTH COAST TOURISM REGION OF INDONESIA.
}

Nofi Yendri Sudiar ${ }^{1}$, Yonny Koesmaryono ${ }^{2}$, Perdinan $^{2}$ and Hadi Susilo Arifin ${ }^{3}$.

1. Post Graduate School of Applied Climatology, Bogor Agricultural University (IPB), Campus of IPB Darmaga, Bogor, 16680, West Java, Indonesia.

2. Post Graduate School of Landscape Architecture, Bogor Agricultural University (IPB), Campus of IPB Darmaga, Bogor, 16680, West Java, Indonesia.

\section{Manuscript Info}

(........................

Manuscript History

Received: 06 July 2019

Final Accepted: 08 August 2019

Published: September 2019

Key words:-

Thermal comfort, thermal sensation, beach tourism, tropical region.

\section{Abstract}

This study explored the use of thermal indices to determine the comfort of coastal tourism areas in the tropics. The study area was chosen at the Ancol Eco-Park (EPA) because this place is a naturebased tourist attraction. Located in the north of Jakarta with an altitude of $3 \mathrm{~m}$ above sea level (masl). The thermal indices used are Physiologically Equivalent Temperature (PET) and Universal Thermal Climate Index (UTCI). Determination of thermal sensations using the 7-region reference namely; PET in Europe, PET in Taiwan, PET in Tianjin, PET in Tel Aviv, UTCI in the Mediterranean, UTCI in Tianjin and UTCI. The category of thermal sensations from the calculation results is compared with the results of the visitor survey. Visitors who became respondents in this study were 219 people. Based on the thermal sensation criteria from 7 EPA reference areas throughout the year, they are not in the comfort zone except PET in Taiwan, namely in January, February and July. Insitu measurement results obtained PET average daily $=34.5^{\circ} \mathrm{C}$ and UTCI daily average $=35.5^{\circ} \mathrm{C}$. The score based on the range of thermal sensations in PET in Taiwan is in the warm (uncomfortable) category. Whereas based on visitors' answers, the score is comfortable. Environmental conditions also provide a comforting effect on visitors because the majority of visitors are interviewed in the shade such as around trees and rest areas.

Copy Right, IJAR, 2019,. All rights reserved.

\section{Introduction:-}

The tourism industry is very sensitive to weather and climate (Nyaupane \& Chhetri, 2009) because this determines where tourists choose their destination. Factors that influence the decision to determine the area to be visited in addition to geographic, topographic, landscape, vegetation and fauna factors are weather and climate factors (Matzarakis, 2006). Means that climate and weather conditions are important for tourism activities. Changing climatic conditions in an area can have negative implications on the quality of services provided, and may reduce the quality of recreational experiences that depend on climate (Moreno \& Becken, 2009; Scott et al., 2004). Therefore the core purpose of resource management and nature-based tourism opportunities is to provide high quality 
experience for visitors to protected areas (Brownlee et al., 2013). Tourists have a tendency to visit / settle in places that provide the highest level of comfort and prosperity with regard to climate and weather (Olya \& Alipour, 2015).

The study of the comfort level of this tour was first conducted by Mieczkowski (1985), known as the Tourism Climate Index (TCI) by using climate variables. This index can represent conditions for 24 hours. But there are also some weaknesses, among others, in terms of climatology which does not include the effects of longwave and shortwave radiation fluxes (Matzarakis et al, 2007), subjective assessment, climate variable weighting system and low data resolution that is using monthly data (Scott et al, 2016). To cover the lack of thermal aspects in TCI, a thermo-physiological index is introduced where the climate element in the form of temperature is associated with physiological factors. Some of these indices include Predicted Mean Vote (PMV), Physiologically Equivalent Temperature (PET), Standard Effective Temperature (SET) (Matzarakis, 2006; Matzarakis et al, 2007; Matzarakis et al, 2014; Farajzadeh \& Matzarakis, 2012) and Universal Thermal Climate Index (UTCI) (Park et al, 2014; Blazejczyk et al, 2012). The advantage of this thermal index is that all of these indices require the same input meteorological parameters namely: air temperature, air humidity, wind speed, short and long wave radiation fluxes.

The use of PET provides more precise information about the thermal conditions of the environment because it combines air temperature, humidity, wind speed and cloud cover (Farajzadeh \& Matzarakis, 2012). Likewise, the use of UTCI can provide satisfactory predictions for outdoor thermal comfort (Lai et al, 2014). Studies of thermal comfort for tourist areas in Indonesia are still very few studies that uses PET and UTCI, most are still using the Thermal Humidity Index (Hadi et al, 2012). Therefore it is important to conduct an in-depth study of the use of these indices for tourist areas due to climatic conditions in Indonesia having equatorial, monsoon and local patterns.

Previous studies and evaluations of the use of PET and UTCI were mostly in sub-tropical and temperate regions, with only a small proportion of Taiwan having a tropical climate. The range of thermal sensation of PET for North China is different from Europe and Taiwan (Lai et al, 2014). It is important to do a classification of thermal perception for each region because the classification is not the same (Lin \& Matzarakis, 2011). PET and UTCI calculations in various regions have been modified, including PET in Europe, PET in Taiwan, PET in Tianjin, PET in Tel Aviv, UTCI in the Mediterranean, UTCI in Tianjin and UTCI. This research aims to determine the thermal sensation of the comfortable category in conducting tourism/recreation activities in nature-based tourism areas in Indonesia with a tropical climate because previously there was no classification of thermal sensation. Comfortable category on 7 thermal sensation references PET and UTCI results calculated compared to the survey results of visitors.

\section{Method:-}

\section{Study Area}

This research was conducted at the Ancol Eco-Park (EPA) which is located in a tropical climate zone and located in a coastal area with an altitude of $3 \mathrm{~m}$ above sea level (masl). The EPA area is a park built on 34 ha of land with a flat topography in accordance with the initial conditions of a golf course. The EPA area is located in the northern coast of Jakarta. Climate classification according to Schmidt-Ferguson, EPA is classified as type $\mathrm{C}$ with a value of $\mathrm{Q}=$ 50.7\%. Climate classification according to Koeppen, EPA has A (tropical forest climate) which has a high temperature. Specifically, the EPA falls into the tropical monsoon climate group with the driest month rainfall $<60$ $\mathrm{mm}(\mathrm{Am})$. The average annual temperature is $28.5^{\circ} \mathrm{C}$ with the lowest temperature of $27.5^{\circ} \mathrm{C}$ in February and the highest temperature of $29.3^{\circ} \mathrm{C}$ in October. Rainfall is $1,623.1 \mathrm{~mm} /$ year with the lowest rainfall of $55.4 \mathrm{~mm}$ in August and the highest rainfall of $476.4 \mathrm{~mm}$ in February. Annual average air humidity is $75.3 \%$, annual average solar radiation is 4.9 hours / day and the average annual wind speed is $4.5 \mathrm{~km} /$ hour.

\section{Data}

The data used in this research is the climate data of Tanjung Priok Maritime Meteorological Station owned by the Climatology and Geophysics Meteorological Agency (BMKG) for 10 years (2008-2017). In situ data measured directly at the EPA are air temperature, humidity and wind speed in April and May 2018 (Table 1). The weather measuring instrument used is the Lutron model ABH-4224 which has met ISO 9001. Surveys and measurements are carried out during the day between 10:00 a.m. to 6:00 p.m. A total of 219 visitors were respondents in this study. Determination of respondents is done by simple random sampling that is a sample taken by simple random sampling. Sampling was carried out inside and outside the tourist area including in the parking lot, around trees, shrubs, bushes, grasslands, ponds/water attractions, pedestrian paths, main roads, rest areas (gazebo/park bench) and others. 
Table 1:-Weather parameter measurement specifications

\begin{tabular}{|c|c|c|c|}
\hline Parameter & Range & Resolution & Accuracy \\
\hline Anemometer & $0.9-35.0 \mathrm{~m} / \mathrm{s}$ & $0.1 \mathrm{~m} / \mathrm{s}$ & $\pm(2 \%+0.2 \mathrm{~m} / \mathrm{s})$ \\
\hline Temperature & $0^{\circ} \mathrm{C}-50^{\circ} \mathrm{C}$ & $0.1^{\circ} \mathrm{C}$ & $\pm 0.8^{\circ} \mathrm{C}$ \\
\hline Humidity & $10 \%-95 \% \mathrm{RH}$ & $0.1 \% \mathrm{RH}$ & $\begin{array}{c}\geq 70 \% \mathrm{RH} \\
\quad \pm(3 \% \text { reading }+1 \% \mathrm{RH}) \\
<70 \% \mathrm{RH}-3 \% \mathrm{RH} \\
\pm 3 \% \mathrm{RH}\end{array}$ \\
\hline
\end{tabular}

\section{Thermal Comfort Indices}

The thermal comfort index used is Physiologically Equivalent Temperature (PET) and Universal Thermal Climate Index (UTCI). PET and UTCI calculations using Rayman Pro software version 2.3 Beta.

PET is based on the thermo-physiological heat balance model known as the Munich energy balance model for individuals (MEMI Model) (Lai et al, 2014). PET is defined as the concept of a balanced temperature that is the same indoor air temperature with outdoor conditions. This specific room means no radiation $(\mathrm{Tmrt}=\mathrm{Ta})$, calm air $(<0.1 \mathrm{~m} / \mathrm{s})$, and air pressure is $1200 \mathrm{~Pa}\left(50 \%\right.$ relative humidity at $\left.20^{\circ} \mathrm{C}\right)$. Thus, PET allows ordinary people to compare the effects of outdoor thermal conditions with their own experiences in the room.

$\mathrm{M}+\mathrm{W}+\mathrm{R}+\mathrm{C}+\mathrm{E}_{\mathrm{D}}+\mathrm{E}_{\mathrm{R} . \mathrm{e}}+\mathrm{E}_{\mathrm{SW}}+\mathrm{S}=0$

Where, $\mathrm{M}$ is the metabolic rate (internal energy production), $\mathrm{W}$ is the output of physical work, $\mathrm{R}$ is the body's clean radiation, $\mathrm{C}$ is convective heat flow, $\mathrm{E}_{\mathrm{D}}$ is latent heat that flows to evaporate water spreading through the skin (invisible sweat), ER .e is the amount of heat flow for heating and moisturizing air, $\mathrm{E}_{\mathrm{SW}}$ is the heat flow due to evaporation of sweat, and $\mathrm{S}$ is the storage heat flow for heating or cooling body mass.

UTCI is defined as the air temperature (Ta) of the reference condition which causes the same model response as the actual condition. Offset, i.e. UTCI deviation from air temperature, depends on the value of the actual air temperature and average radiation temperature (Tmrt), wind speed (va) and humidity expressed as water vapor pressure (vp) or relative humidity $(\mathrm{RH})$. Mathematically written;

UTCI $=\mathrm{f}(\mathrm{Ta} ; \mathrm{Tmrt} ; \mathrm{va} ; \mathrm{vp})=\mathrm{Ta}+$ Offset $(\mathrm{Ta} ; \mathrm{Tmrt} ; \mathrm{va} ; \mathrm{vp})$

For the reference environment, it was decided to use:

1. Wind speed (va) $\cong 0.5 \mathrm{~m} / \mathrm{s}$ at $10 \mathrm{~m}$ altitude (approximately $\cong 0.3 \mathrm{~m} / \mathrm{s}$ at $1.1 \mathrm{~m}$ altitude)

2. Average radiation temperature (Tmrt) equals air temperature (Ta)

3. Vapor pressure (vp) representing 50\% relative humidity, at high air temperatures $\left(>29{ }^{\circ} \mathrm{C}\right)$ the reference humidity is taken to be constant at $20 \mathrm{hPa}$.

\section{Results:-}

\section{Historical thermal comfort}

Calculation of thermal comfort using PET and UTCI with historical data for 10 years (2008-2017). PET and UTCI are monthly values (Table 2 ).

Table 2:-Monthly PET

\begin{tabular}{|l|l|l|l|l|l|l|l|l|l|l|l|l|}
\hline Year & Jan & Feb & Mar & Apr & May & Jun & Jul & Aug & Sep & Oct & Nov & Dec \\
\hline 2008 & 29.3 & 28.4 & 29.1 & 29.8 & 28.4 & 29.5 & 27.9 & 28.0 & 30.4 & 30.8 & 30.5 & 29.5 \\
\hline 2009 & 29.0 & 28.6 & 28.7 & 30.4 & 30.6 & 29.6 & 29.8 & 30.3 & 31.2 & 31.6 & 30.5 & 30.7 \\
\hline 2010 & 29.2 & 29.8 & 30.6 & 31.6 & 31.1 & 30.4 & 30.3 & 30.6 & 29.6 & 30.1 & 30.9 & 29.2 \\
\hline 2011 & 29.5 & 29.4 & 29.5 & 29.9 & 30.7 & 30.0 & 29.2 & 29.6 & 30.0 & 31.0 & 31.0 & 30.7 \\
\hline 2012 & 29.3 & 30.3 & 29.7 & 30.6 & 30.5 & 30.4 & 30.1 & 29.8 & 31.8 & & 31.8 & 31.4 \\
\hline 2013 & 28.3 & 30.0 & 32.3 & 31.0 & 31.2 & 32.1 & 29.9 & 31.3 & 31.4 & 31.6 & 31.3 & 30.1 \\
\hline 2014 & 29.2 & 29.7 & 30.9 & 31.3 & 31.7 & 31.2 & 30.5 & 30.3 & 31.3 & 32.1 & 31.8 & 30.8 \\
\hline 2015 & 29.2 & 29.5 & 30.4 & 30.8 & 30.9 & 30.6 & 29.7 & 29.7 & 30.4 & 31.4 & 32.1 & 31.1 \\
\hline 2016 & 31.6 & 30.7 & 31.3 & 31.4 & 31.6 & 31.3 & 30.5 & 30.6 & 30.9 & 31.7 & 31.4 & 30.1 \\
\hline 2017 & 29.7 & 29.1 & 30.5 & 30.9 & 32.1 & 30.8 & 31.3 & 30.6 & 30.9 & 31.8 & 31.0 & 30.1 \\
\hline Average & 29.4 & 29.5 & 30.3 & 30.8 & 30.9 & 30.6 & 29.9 & 30.1 & 30.8 & 31.3 & 31.2 & 30.4 \\
\hline
\end{tabular}


The lowest average PET score was $29.4^{\circ} \mathrm{C}$ in January and the highest was $31.3^{\circ} \mathrm{C}$ in October. Throughout the year fluctuations in PET scores were not too large, namely $1.9^{\circ} \mathrm{C}$. There is no significant difference in PET scores between the rainy season and the dry season. Evidenced by the absence of scores that are too extreme in one season. To determine the thermal sensation of the EPA region we use several references, namely PET in Europe, PET in Taiwan, PET in Tianjin and PET in Tel Aviv (Table 3).

Table 3:-Thermal sensation ET.

\begin{tabular}{|c|c|c|c|c|}
\hline Thermal sensation & $\begin{array}{l}\text { PET in Europe } \\
\left({ }^{0} \mathrm{C}\right)^{1}\end{array}$ & $\begin{array}{l}\text { PET in Taiwan } \\
\left({ }^{0} \mathrm{C}\right)^{1}\end{array}$ & $\begin{array}{l}\text { PET in Tianjin } \\
\left({ }^{0} \mathrm{C}\right)^{1}\end{array}$ & $\begin{array}{l}\text { PET in Tel Aviv } \\
\left({ }^{0} \mathrm{C}\right)^{2}\end{array}$ \\
\hline Very cold & $<4$ & $<14$ & $<-16^{*}$ & $<8$ \\
\hline Cold & $4-8$ & $14-18$ & $-16-(-11)^{*}$ & $8-12$ \\
\hline Cool & $8-13$ & $18-22$ & $-11-(-6)^{*}$ & $12-15$ \\
\hline Slightly cool & $13-18$ & $22-26$ & $-6-11$ & $15-19$ \\
\hline Neutral & $18-23$ & $26-30$ & $11-24$ & $19-26$ \\
\hline Slightly warm & $23-29$ & $30-34$ & $24-31$ & $26-28$ \\
\hline Warm & $29-35$ & $34-38$ & $31-36$ & $28-34$ \\
\hline Hot & $35-41$ & $38-42$ & $36-46^{*}$ & $34-40$ \\
\hline Very hot & $>41$ & $>42$ & $>46^{*}$ & $>40$ \\
\hline
\end{tabular}

Note:

$*$ = sensation values are obtained from linear regression

$1=($ Lai et al, 2014)

$2=($ Cohen et al, 2013)

We compare the monthly average PET value with some of the references available to determine the category of thermal sensations in the EPA region. Based on PET in Europe and Tel Aviv, the thermal sensation in the EPA region is warm all year round. Based on PET in Taiwan, there are two thermal sensations in the EPA region, namely slightly warm (Mar-Jun and Aug-Dec) and neutral (Jan, Feb and July). Based on PET in Tianjin, the thermal sensation of the EPA region is slightly warm (Jan-Sep and Dec) and warm (Oct and Nov).

Table 4:-Montly UTCI

\begin{tabular}{|l|l|l|l|l|l|l|l|l|l|l|l|l|}
\hline Year & Jan & Feb & Mar & Apr & May & Jun & Jul & Aug & Sep & Oct & Nov & Dec \\
\hline 2008 & 30.6 & 29.8 & 30.6 & 31.4 & 29.5 & 30.7 & 28.1 & 28.3 & 31.4 & 31.9 & 31.8 & 30.7 \\
\hline 2009 & 30.4 & 30.1 & 29.4 & 31.3 & 32.1 & 30.1 & 30.8 & 31.3 & 32.0 & 32.6 & 31.6 & 32.1 \\
\hline 2010 & 30.7 & 31.6 & 32.2 & 32.7 & 32.6 & 32.0 & 31.7 & 31.8 & 31.3 & 31.5 & 32.1 & 30.3 \\
\hline 2011 & 30.8 & 30.8 & 30.5 & 31.3 & 32.1 & 31.2 & 30.5 & 30.6 & 31.0 & 32.1 & 32.2 & 31.9 \\
\hline 2012 & 30.6 & 31.8 & 30.9 & 32.1 & 31.9 & 31.5 & 31.1 & 30.8 & 32.3 & & 33.0 & 32.6 \\
\hline 2013 & 29.3 & 31.5 & 33.3 & 32.5 & 32.8 & 33.1 & 31.0 & 32.0 & 32.6 & 32.7 & 32.4 & 31.7 \\
\hline 2014 & 30.8 & 31.5 & 32.5 & 32.8 & 33.2 & 32.8 & 31.9 & 31.5 & 32.5 & 32.9 & 33.0 & 32.1 \\
\hline 2015 & 30.7 & 31.3 & 32.0 & 32.3 & 32.2 & 31.7 & 30.7 & 30.9 & 31.3 & 32.2 & 33.3 & 32.6 \\
\hline 2016 & 33.2 & 32.4 & 33.1 & 33.0 & 33.4 & 32.7 & 32.0 & 32.0 & 32.3 & 32.7 & 32.6 & 31.0 \\
\hline 2017 & 31.1 & 30.9 & 32.0 & 32.4 & 33.2 & 32.3 & 32.2 & 31.4 & 32.0 & 32.9 & 32.3 & 31.2 \\
\hline Average & 30.8 & 31.2 & 31.7 & 32.2 & 32.3 & 31.8 & 31.0 & 31.1 & 31.9 & 32.4 & 32.4 & 31.6 \\
\hline
\end{tabular}

The lowest UTCI average is $30.8^{\circ} \mathrm{C}$ in January and the highest is $32.4^{\circ} \mathrm{C}$ in October and November. Throughout the year the UTCI score difference is not too large, which is $1.6^{\circ} \mathrm{C}$. Neither the rainy season nor the dry season, UTCI scores did not differ significantly. To determine the thermal sensation of the EPA region we use several references, namely UTCI in the Mediterranean, UTCI in Tianjin and UTCI (Table 5).

Table 5:-Thermal sensation UTCI

\begin{tabular}{|l|l|l|l|}
\hline Thermal sensation & $\begin{array}{l}\text { UTCI in Mediterania } \\
\left({ }^{0} \mathrm{C}\right)\end{array}$ & UTCI in Tianjin $\left({ }^{0} \mathrm{C}\right)^{1}$ & UTCI $\left({ }^{0} \mathrm{C}\right)^{1}$ \\
\hline Extreme cold stress & $<4.1$ & $<-21^{*}$ & $<-40$ \\
\hline Very strong cold stress & $4.1-5.9$ & $-21-(-16)^{*}$ & $-40-(-27)$ \\
\hline Strong cold stress & $5.9-9.1$ & $-16-(-11)^{*}$ & $-27-(-13)$ \\
\hline Moderate cold stress & $9.1-14.0$ & $-11-(-6)^{*}$ & $-13-0$ \\
\hline
\end{tabular}




\begin{tabular}{|l|l|l|l|} 
Slight cold stress & $14.0-17.4$ & $-6-12$ & $0-9$ \\
\hline No thermal stress & $17.4-24.5$ & $12-25$ & $9-26$ \\
\hline Moderate heat stress & $24.5-29.1$ & $25-33$ & $26-32$ \\
\hline Strong heat stress & $29.1-34.1$ & $33-39$ & $32-38$ \\
\hline Very strong heat stress & $34.1-37.7$ & $39-47^{*}$ & $38-46$ \\
\hline Extreme heat stress & $>37.7$ & $>47 *$ & $>46$ \\
\hline
\end{tabular}

Note

* = sensation values are obtained from linear regression

$1=($ Lai et al, 2014)

We compare the monthly average UTCI value with some of the references available to determine the category of thermal sensations in the EPA region. Based on UTCI in the Mediterranean, the thermal sensations in the EPA region include strong heat stress throughout the year. According to UTCI in Tianjin, the thermal sensation in the EPA region includes moderate heat stress throughout the year. Based on UTCI, the thermal sensations in the EPA region include moderate heat stress (Jan-Sep and Dec) and strong heat stress in October and November. From 7 reference regions, the thermal sensation used shows that the highest PET and UTCI values occur in the transition season (September-October-November, SON), namely warm and strong heat stress.

\section{Thermal comfort during surveys}

Determination of thermal sensations felt by visitors to the EPA tourist area based on answers given from questionnaire questions. Using closed questions, visitors are asked the thermal sensation they feel. The answer choices are divided into seven categories including very hot, hot, slightly hot, neutral, slightly cold, cold and very cold. Simultaneously before visitors give their answers, measurements of air temperature, humidity and wind speed are taken (Table 6).

Tabel 6:-Measurement of weather parameters at EPA

\begin{tabular}{|l|l|l|l|}
\hline & Temperature $\left({ }^{\circ} \mathrm{C}\right)$ & Relatif Humidity $(\%)$ & Wind speed $(\mathrm{m} / \mathrm{s})$ \\
\hline Minimum & 30.2 & 52.0 & 0.1 \\
Average & 32.5 & 62.3 & 0.5 \\
Maximum & 34.9 & 70.2 & 2.6 \\
\hline
\end{tabular}

A total of 219 respondents were asked, as many as 133 respondents $(60.7 \%)$ answered that the thermal sensation in the EPA region was neutral, 52 respondents $(23.7 \%)$ answered slightly hot and 28 respondents $(12.88 \%)$ answered hot (Fig 1). The majority of visitors feel the thermal conditions are pleasant for a tourist visit. Calculation of thermal comfort using insitu data gives the following results; PET daily average $=34.5^{\circ} \mathrm{C}$ and UTCI daily average $=35.5^{\circ}$ C. These results illustrate that with PET and UTCI values in the range of $34.5^{\circ} \mathrm{C}$ and $35.5^{\circ} \mathrm{C}$ the majority of visitors stated the thermal sensation was neutral. If we look at the existing thermal sensation categories, the values of $34.5^{\circ} \mathrm{C}$ and $35.5^{\circ} \mathrm{C}$ are at the level of warm, hot (PET thermal sensation), strong heat stress and very strong heat stress (UTCI thermal sensation).

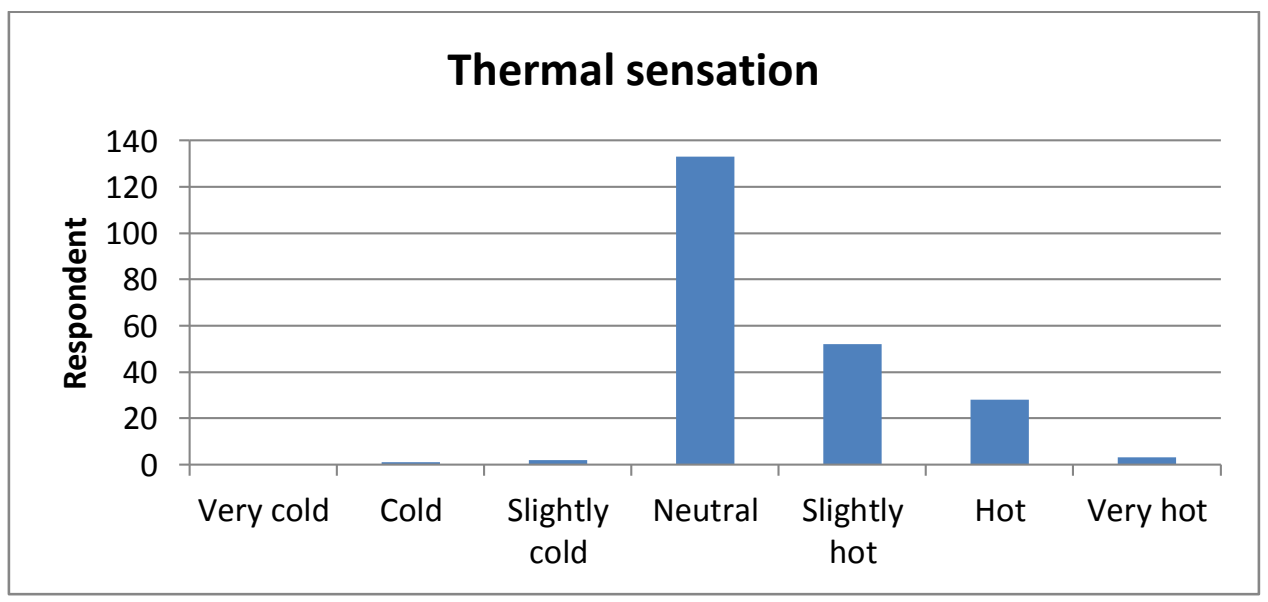

Fig 1:-Thermal sensation felt by visitors in the EPA 
197 people (90\%) of visitors were interviewed inside the EPA tourist site and the rest outside the EPA area. Location of interviewees and measurements of weather parameters, among others; parking lots, surrounding trees, shrubs, bushes, grasslands, water attractions, pedestrian paths, rest areas (gazebos/park benches) and main roads (Table 7). The majority of visitors were interviewed in the shade, such as trees and rest areas $(50.7 \%)$.

Table 7:-Location of data collection

\begin{tabular}{|l|l|l|}
\hline The landscape & Person & Percentage $(\%)$ \\
\hline Parking lot & 13 & 5.9 \\
\hline Trees & 51 & 23.3 \\
\hline Shrubs & 20 & 9.1 \\
\hline Bushes & 3 & 1.4 \\
\hline Grasslands & 15 & 6.8 \\
\hline Water recreations & 35 & 16.0 \\
\hline Pedestrian paths & 17 & 7.8 \\
\hline Main roads & 3 & 1.4 \\
\hline Rest area (gazebo/park benches) & 60 & 27.4 \\
\hline Others & 2 & 0.9 \\
\hline Total & 219 & 100 \\
\hline
\end{tabular}

\section{Discussion:}

Based on reference to thermal comfort categories (PET in Europe, PET in Taiwan, PET in Tianjin, PET in Tel Aviv, UTCI in the Mediterranean, UTCI in Tianjin and UTCI) shows that the EPA region throughout the year is not in the thermal comfort zone, except for PET Taiwan. Scores that indicate the EPA area is comfortable throughout the year according to PET in Taiwan are only on the minimum PET calculation (Fig. 2). While interviews with visitors showed the opposite, with an average PET score $=34.5^{\circ} \mathrm{C}$ and an average UTCI $=35.5^{\circ} \mathrm{C}$ the majority stated neutral, which means comfortable. The PET and UTCI calculation scores indicate values that are close to the thermal comfort zone with the result of the visitor interview being the Taiwan PET because some parts of Taiwan are tropical. These results challenge us to determine the classification of thermal comfort, especially for the tropics.

According to our analysis, local visitors feel at ease in uncomfortable zones based on existing references because the annual temperature difference is not too high. This allows local people to become accustomed to the situation and feel comfortable. The temperature difference is also not too large between the dry season and the rainy season. Furthermore, environmental conditions also provide a comfort impact on visitors. The majority of visitors were interviewed in the shade. Although the measured air temperature is classified as "high", the effect of trees and rest areas makes visitors feel comfortable.

The results of this study illustrate that it is important to classify thermal perception in Indonesia. The range of thermal comfort needs to be explored further to provide an adequate and appropriate picture according to each region. Indonesia, which is located on the equator, causes variations in temperature throughout the year is very small. So the difference in PET and UTCI scores did not differ significantly in the dry season and rainy season. PET and UTCI scores tend to be higher in October and November because that month is a transition from the dry season to the rainy season. The sun reaches its culmination point at the equator and the energy received at the maximum equatorial area (Tjasyono, 2003) results in a temperature that tends to rise. In addition, there is also a low pressure around the equator that is enough to make increased connectivity and affect the absorption of solar energy in the surface layer of the earth (Fadholi, 2013). 


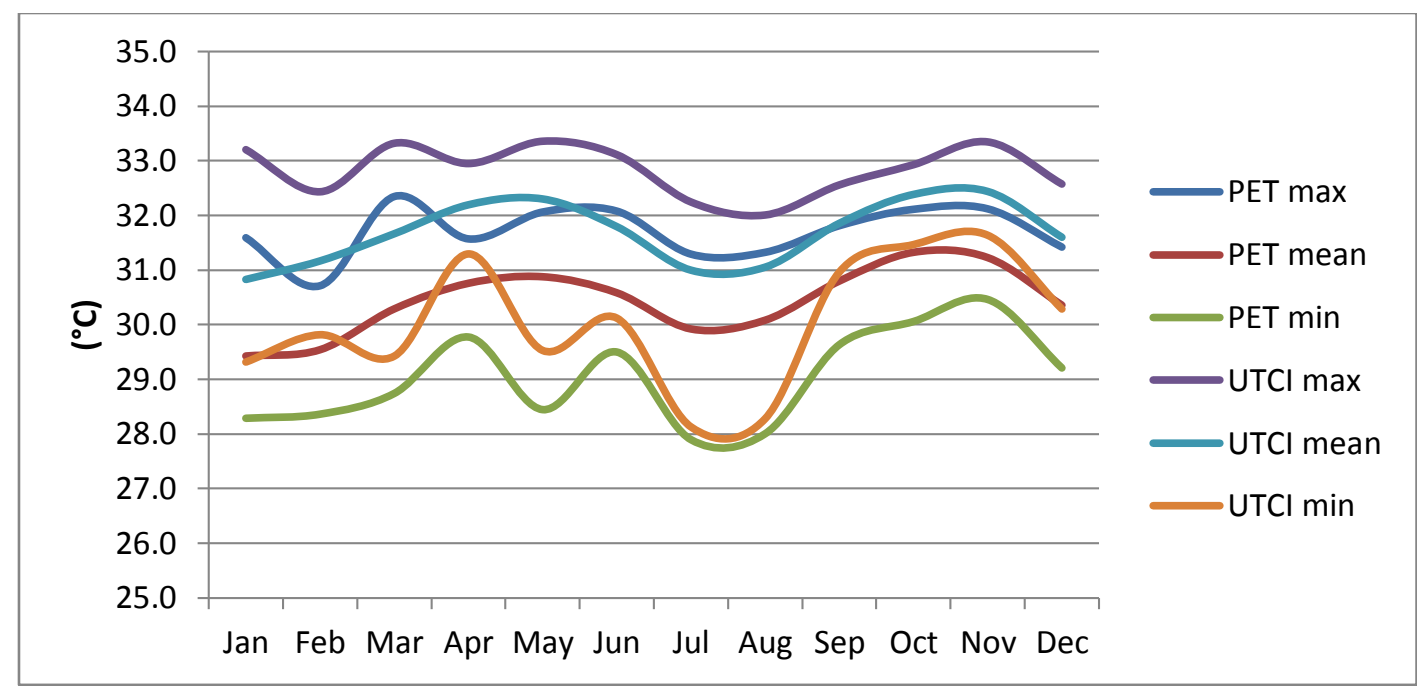

Fig 2:-Annual variation of max, mean and min PET and UTCI of EPA for 2008-2017.

\section{Conclusions:-}

Based on the thermal sensation criteria of 7 references (PET in Europe, PET in Taiwan, PET in Tianjin, PET in Tel Aviv, UTCI in the Mediterranean, UTCI in Tianjin and UTCI) the EPA region throughout the year is not in the comfort zone except PET in Taiwan. Comfortable criteria namely in January, February and July. Calculation results using historical data show a monthly average PET score lower than the monthly average UTCI score. The fluctuation of PET and UTCI scores is small so there is no significant difference between the rainy season and the dry season.

Using insitu measurements, the average daily PET score is $34.5^{\circ} \mathrm{C}$ and the daily average UTCI is $35.5^{\circ} \mathrm{C}$. The score is based on the range of thermal sensations on PET in Taiwan is the warm (uncomfortable) category. Whereas based on visitors' answers, the score is comfortable. Local visitors feel comfortable because the temperature variation throughout the year is very small, so they have adapted to the situation. Environmental conditions also provide a comforting effect on visitors because the majority of visitors are interviewed in the shade such as around trees and rest areas.

\section{References:-}

1. Blazejczyk K, Epstein Y, Jendritzky G, Staiger H, Tinz B. 2012. Comparison of UTCI to selected thermal indices. Int J Biometeorol vol 56:515-535. DOI 10.1007/s00484-011-0453-2.

2. Brownlee M, Hallo J, Krohn B. 2013. Botanical garden visitors' perceptions of local climate impacts: Awareness, concern, and behavioral responses. Managing Leisure, 18(2), 97-117.

3. Cohen Pninit, Potchter Oded, Matzarakis A. 2013. Human thermal perception of Coastal Mediterranean outdoor urban environments. Applied Geography 37: 1-10. Elsevier.

4. Fadholi Akhmad. 2013. Uji Perubahan Rata-Rata Suhu Udara Dan Curah Hujan Di Kota Pangkalpinang. Jurnal Matematika Sains Dan Teknologi, Vol. 14, No. 1, P. 11-25. ISSN 2442-9147.

5. Farajzadeh H, Matzarakis A. 2012. Evaluation of thermal comfort conditions in Ourmieh Lake, Iran. Theoretical and Applied Climatology, 107(3-4), 451-459. http://doi.org/10.1007/s00704-011-0492-y

6. Hadi R, Lila K A, Gunadi I G A. 2012. Evaluasi Indeks Kenyamanan Taman Kota (Lapangan Puputan Badung I Gusti Ngurah Made Agung) Denpasar, Bali. E-Jurnal Agroekoteknologi Tropika, 1(1), 34-45. http://doi.org/EJurnal Agroekoteknologi Tropika ISSN: 2301-6515 Vol. 1, No. 1.

7. Lai Dayi, Guo Deheng, Hou Yuefei, Lin Chenyi, Chen Qingyan. 2014. Studies of outdoor thermal comfort in northern China. Building and Environment 77: 110-118 Contents. Elsevier.

8. Lin Tzu-Ping, Matzarakis Andreas. 2011. Tourism climate information based on human thermal perception in Taiwan and Eastern China. Tourism Management 32: 492-500 Contents. Elsevier.

9. Matzarakis, A. 2006. Weather and climate related information for tourism. Tourism and Hospitality Planning \& Development, 3(2), 99-115. http://doi.org/10.1080/14790530600938279. 
10. Matzarakis A, Endler C, Nastos P T. 2014. Quantification of climate-tourism potential for Athens, Greece Recent and future climate simulations. Global Nest Journal, 16(1), 43-51.

11. Matzarakis A, Freitas C R De, Scott D. 2007. Assessment Method for Climate and Tourism Based on Daily. Tourism, 52-58.

12. Mieczkowski.1985. The Tourism Climat Index: A Method of Evaluating World Climate for Tourism. The Canadian Geographer / Le Geographe canadien 29, no 3 I1 985) 220-33.

13. Moreno A, Becken S. 2009. A climate change vulnerability assessment methodology for coastal tourism. Journal of Sustainable Tourism, 17(4), $473-488$. http://dx.doi.org/10.1080/09669580802651681.

14. Nyaupane G P, \& Chhetri N .2009. Vulnerability to climate change of nature-based tourism in the Nepalese Himalayas. TourismGeographies, 11(1), 95-119. http://dx.doi.org/10.1080/14616680802643359.

15. Olya H G T, Alipour H. 2015. Risk assessment of precipitation and the tourism climate index. Tourism Management, 50, 73-80. http://doi.org/10.1016/j.tourman.2015.01.010.

16. Park S, Tuller S E, Jo M. 2014. Application of Universal Thermal Climate Index (UTCI) for microclimatic analysis in urban thermal environments. Lanscape and Urban Planning 125, 146-155. Elsevier.

17. Scott D, McBoyle G, Schwartzentruber M. 2004. Climate change and the distribution of climatic resources for tourism in North America. Climate Research, 27(2), 1005-117. http://dx.doi.org/10.3354/cr027105.

18. Tjasyono Bayong HK. 2003. Geosains. Penerbit ITB. Bandung. 